\title{
VALIDITY, RELIABILITY AND SENSITIVITY OF THE TEST STROKE WITH LEG MAE GERI
}

\author{
Žarko Kostovski ${ }^{1}$, Marko Zeljković ${ }^{2}$, Lulzim Ibri ${ }^{3}$, Elena Soklevska ${ }^{4}$, and Boško Zaborski ${ }^{4}$ \\ ${ }^{1}$ Faculty of Physical Culture, University "Ss. Cyril and Methodius" of Skopje, Macedonia \\ ${ }^{2}$ Faculty of Physical Education and Sports, University of Banja Luka, \\ Bosnia and Herzegovina \\ ${ }^{3}$ Sector of Sport, Community Prizren, Serbia \\ ${ }^{4}$ Karate club "Mak Petrol",Skopje, Macedonia
}

\section{SUMMARY}

Specific motor abilities in modern sport are probably the determining factor for solving sports tasks and achieving sport success. Strockes with an arm and leg in karate sport are dominant techniques which help a karate athlete to score points or win a fight. Karate sport and particularly sports discipline fight (kumite) is characterized with poly structural movements, and the most important motor skills are explosiveness, speed and coordination. The subject of this research derives from the previous knowledge and arguments and it is directed toward determination of the measuring characteristics (reliability, sensitivity and validity) of the specific "Mae Geri" motor test.

The research has been conducted in the Republic of Macedonia with an intentional sample of 30 male examinees (karate athletes), at the age older then 18. During the research with the sample of examinees, 1 (one) manifest specific-motor variable (newly constructed composite test) was applied, characteristic for the karate sport. The aim of this research was to determine the measuring characteristics of the newly constructed test. Using the Hoteling method, the factor validity of this test was determined, as well as its latent dimensions, and the main component according to Kaiser-Gutman criterion were established. Based on the obtained results of the research, there have been some conclusions which refer to the measuring characteristics of the applied test, and primarily to the factor validity, sensitivity and reliability of the same.

Key words: karate, Mae-Geri, mesure characteristics.

\section{INTRODUCTION}

The karate sport, and particularly the fight (kumite) sport discipline, is characterized with poly structural movements, and the most significant motor abilities are explosiveness, velocity and coordination. The specific motor abilities in the modern sport are probably the crucial factor for solving sport tasks and achieving sport success. The arm and leg strokes in karate sport are dominant techniques that help the athlete to score points or win a fight. The poly structural movement characteristics in a karate fight (kumite) largely define the driving structure and its most important background motor characteristics: agility, explosiveness and speed. So far researches with modern technical and tactical indicators in karate fight show that different techniques have the greatest impact (Koropanovski, Dopsaj, \& Jovanović 2008).

Some knowledge about the motor skills development level can be obtained by assessing various manifestations registered with appropriate motor tests, so-called measuring instruments. Since human motor skills are measured indirectly, the complete measuring procedure must be standardized, and motor tests (measuring instruments) should be characterized with satisfactory measurement characteristics such as: validity, reliability, sensitivity, accuracy and so on. In this case, the obtained results in a motor ability with 
a sample of respondents could be compared with the results obtained with another sample of respondents of the same capacity (Kostovski \& Georgiev 2009a).

Major development of karate as a sport requires modern approaches, concepts, forms, activities and procedures in training the latest karate technologies, especially concerning the structure of anthropological features, their correlations and specific impacts on athletic performances. In addition, it is necessary to establish the diagnosis and the validity of the instruments used for modeling, diagnosis, planning, programming and monitoring of the effects of training process operationalization (Doder, Malacko, Stanković, \& Doder, 2011).

Starting from this fact, some researches have been undertaken that refer to establishing tests for evaluation of some specific motor characteristics with karate athletes (Костовски 2005; Kostovski \& Georgiev 2009b,; Kostovski, Masić \& Djukanović, 2011).

Some measurement instruments that showed as "good" for a population or sample, are not necessary "good" for other population or sample. Especially in a case when examinees are of different ages, different sex or have other different characteristics. According to this research problem, there is a need for constant checking of the measurement characteristics of the tests. In this regard Костовски (2004) conducted a research to determine the measurement characteristics of some standards and specific motor tests in karate athletes of a different chronological age. In this regard Костовски (2004) conducted research to determine the measurement characteristics of some standard and specific motor tests in karate from a different chronological age.

Given the fact that the human motor reactions can be realized only with the assessment of motor skills through a variety of manifestations, they can be registered through various motor procedures - measuring instruments (Kostovski \& Georgiev, 2009c)

Over the past period, researchers have used the existing tests for motor ability assessment of karate athletes (Koletić, 1992; Kuleš \& Muratagić, 1993). However, these tests have not proved entirety specific to satisfy the needs of today's karate sport

The aforementioned conclusions point out the need for the implementation of new researches aimed for constructing and establishing new tests and checking their metric characteristics (Kostovski \& Georgiev 2009c)

Since the application of diagnostic morphological characteristics and basic motor skills in the training process of karate athletes are related with interdisci- plinary approach, where the complexity of movable structures and anthropological interdisciplinary characteristics of the character is high, it is necessary to include as many basic, specific and situational measuring instruments as possible. While for construction of instruments you have to bear in mind the information validity for each measuring instrument, which means that the applied instruments must have satisfactory measuring features, such as validity, objectivity, reliability, discrimination (Doder et al., 2011).

In order to conduct better kinesiology researches, in recent times measuring instruments have been used for registering and measuring specific motor ability manifestations (Sertic, Vidranski, \& Segedi, 2010), and the athletes' training process has been largely planned, programmed and monitored

However, for a test to be valid and applicable it has to be reliable too. Knowledge of specific requirements in karate can help coaches, and even athletes to optimize the training program (Chaabène et. al., 2012).

Based on these considerations, this study was conducted with the main objective to identify, analyze and compare the measurement characteristics of the specific motor variable Mae Geri in top karate athletes.

\section{METHODS}

\section{Sample of respondents}

The research was covered with 30 karate athletes, standard and potential representatives from Macedonia, at the age of +18 , defined as karate athletes-seniors. The research was realized on a target sample of male participants.

\section{Sample of variables}

In this research on the sample of participants was applied 1 manifest specific motor variable for evaluating of the specific karate frequency of the more effective leg.

1. Stroke with leg on bag MAE GERI with the more effective leg in $10 \mathrm{~s}$ (MAEG)

\section{Test description}

The test is performing in sport gym, in the gym where karate athletes have their training. For performing the test there must be a punching bag attached to the wall, and stopwatch with which the measure men will measure the time. The participant stands in front of the bag in characteristical fighting pose "fu- 


\section{TABLE 1}

Basic statistical parameters of the test Stroke with leg on bag - Mae Geri.

\begin{tabular}{lrrrrrrr}
\hline & $n$ & \multicolumn{1}{c}{$M$} & Min & Max & $S D$ & Skew. & Kurt. \\
\hline MAEG1 & 30 & 10.87 & 6 & 16 & 2.58 & .22 & -.80 \\
\hline MAEG2 & 30 & 9.43 & 5 & 16 & 2.53 & .68 & .44 \\
\hline MAEG3 & 30 & 9.47 & 5 & 15 & 2.40 & .38 & -.24 \\
\hline MAEG4 & 30 & 10.03 & 5 & 15 & 2.27 & .09 & -.97 \\
\hline
\end{tabular}

Legend: $\mathbf{n}$ - Number of respondent; $\mathbf{M}$ - Mean; Min - Minimum; Max - Maximum; SD -

Standard deviation; Skew - Skewness; Kurt - Kurtosis; MAEG - Stroke with leg on

bag - Mae Geri; 1-4 - First, second, third and fourth repetition of the test.

TABLE 2

Matrix of item intercorrelation of the test Stroke with leg on bag - Mae Geri.

\begin{tabular}{l|rrrr}
\hline & MAEG1 & MAEG2 & MAEG3 & MAEG4 \\
\hline MAEG1 & 1.00 & & & \\
\hline MAEG2 & .93 & 1.00 & & \\
\hline MAEG3 & .94 & .94 & 1.00 & \\
\hline MAEG4 & .95 & .87 & .89 & 1.00 \\
\hline
\end{tabular}

Legend: MAEG - Stroke with leg on bag - Mae Geri; 1-4 - First, second, third and fourth repetition of the test (Prvo, drugo, treće i četvrto ponavljanja testa).

TABLE 3

Hotelling procedure.

\begin{tabular}{lll}
\hline & $H$ & $T^{2}$ \\
\hline MAEG1 & .985 & $\mathbf{. 8 6}$ \\
\hline MAEG2 & .965 & $\mathbf{. 8 6}$ \\
\hline MAEG3 & .971 & $\mathbf{. 9 0}$ \\
\hline MAEG4 & .956 & $\mathbf{. 8 6}$ \\
\hline
\end{tabular}

do daci" on a distance which define himself according to the length of his leg. The sportsman task is to perform correct as much as possible more strokes "mae geri" with the effective leg in 10 seconds. The measure men stands on the side, turns on the stopwatch when the participant will start with the performance of the test and count the correct performed strokes in time of 10 seconds. The test is repeated 4 times with break between every repetition.

\section{Methods for data processing}

The data's obtained from the manifested specific motor test, were processed with the necessary statistical methods which are in function of the goals and tasks of this research. In the data's processing the measurements of the specific motor test, for every
TABLE 4

Reliability coefficient.

\begin{tabular}{lr}
\hline$\dot{\alpha}$ & .977 \\
$r_{n}$ & .978 \\
$I C C$ & .923 \\
\hline$\lambda$ & 3.757 \\
$\%$ & 93.915 \\
\hline
\end{tabular}

composite repetition, were calculated the basic central and dispersive statistical parameters, arithmetic's mean $(M)$, standard deviation $(S D)$, minimal (Min), and maximal (Max) score. Based on symmetry of the distributions of the result it has been evaluated that some test represent easier or harder motor task for the participants (Skew.), and from the roundness of the distribution of the results it have been determine the homogeneity of the results in the same test (Kurt.). The sensitivity as measuring performance was determined by the relationship between the mean and standard deviation. For determent of the correlation between the items there was calculated Pierce coefficient of correlation $(r)$. Factor validity of the variables was determined with the Hotelling procedure, and there were calculated the latent dimensions of 
the variables, were the main components were determined by Kaiser-Guttmann criteria, and there were obtained: item projections of the main component $(H)$, values of the isolated characteristic square root ( $\lambda$ ) and contribution of the isolated characteristic square roots in the explanation of the total variability of the variance expressed in percents (\%). Inter validity of the items was determined by the item projections of the first main component, or by the isolated characteristic square root $(H)$. The mutual subject of the measure was determined by the value of the characteristic square root $(\lambda)$. To determine the reliability there were calculated more coefficients and indexes of reliability, including: Cronbach index for reliability, calculated by the item projections with the first main component (Cronbach- $\dot{\alpha}$ ), Spearman-brown coefficient of reliability $\left(r_{n}\right)$ - calculated on the base of middle correlations between composites measures for each test individually, and interclass correlation coefficent for every test individually (ICC).

\section{RESULTS AND DISCUSSION}

Analyzing the values of the means of the four of the applied item of this variable, we can conclude next: in the first and fourth item there were achieved high results in relation with the rest two items, where there is moderate decline of the numbers of repetitions per unit time. All of the four values represent the real condition of the stability in terms of performing the treated test, and the small positive change which appears in these two items must be result of the motivation of the athletes, in performing of the first and fourth attempt to give their maximum. The test possesses relatively good discrimination, on which indicates the value of the variability, or the standard deviations.

According to the tilt of the distribution of the results in the items, we can conclude that this test represents relatively easy task for the treated sample of participants (the mean of the four items is in the zone of middle results). For the four items of this test there was determined normal distribution of the results. The values of the correlation coefficient between the items are very high, positive and statistically significant with values of .87 to .95

In this variable there was determined that the all four items have mutual subject of measure, and relatively higher homogeneity of this variable, indicating on the value of the isolated characteristic square root of the first main component $\lambda=3.757$ and explains $93.915 \%$ of the total variability of the variance. The reliability coefficients (Cronbach $\alpha=.977$ and Spearman-Brown $=.978)$ are very high and with satisfying values, as for the inter correlation which is .923. According to the above mentioned for the variable "Mae Geri", we can say that: the test features with high degree of sensitivity and satisfying reliability coefficient. Also the test is simple for application and easy for explanation.

According to Bukvić (1982) every reliability coefficient with value bigger than .80 indicates to high reliability of the tests, and values bigger than .90 indicates on very high reliability.

\section{CONCLUSION}

The research was conducted on target sample of 30 participants (karate athletes), males from Macedonia, at the age of +18 (karate athletes-seniors). On the sample of participants was applied 1 (one) manifest specific motor variable (newly constructed composed test), characteristic for the karate sport.

The obtained results from the research lead us to the following conclusions which concern the measuring performance of the applied variable, and before all, the factor validity, sensitivity and reliability of the same.

The test "Mae Geri" features with high degree of sensitivity and satisfying reliability coefficients, which means that the eventual error in the measurements is very small.

- The reliability coefficients (Cronbach $\alpha=.977$ and Spearman-Brown $=.978)$ are very high and with satisfying values, as for the inter correlation which is .923. Also the test is simple for application and easy for explanation.

The test evaluates the motor dimensions defined as specific karate frequency of the lower extremities.

From the obtained results, the test should be recommended in the training technology and selection of the karate athletes in the test battery for evaluating of the specific karate frequency of the lower extremities (until constructing a new test).

\section{REFERENCES}

Bukvić, A. (1982). Načela iz̧rade psiboloških testova [Principals of psychological tests]. Beograd, RS: Zavod za udžbenike i nastavna sredstva.

Chaabène, H., Hachana, Z., Attia, A., Mkaouer, B., Chaabouni, S, \& Chamari, K. (2012). Relative and absolute reliability of karate specific aerobic test (ksat) in experienced male athletes. Biolo. Sport, 29(3), 211-215. doi: 10.5604/20831862. 1003485

Doder, D., Malacko, J., Stanković, V., \& Doder, R. (2011). Predictor validity of morphological and 
basic motor variables for assessment and monitoring of the karate punch with the lead arm (oi-tsuki). Biolo. Sport, 28(4), 265-270. doi: $10.5604 / 965485$

Koletić, Z. (1992). Metrijske karakteristike situaciono motoričkih testova $u$ karate [Metric characteristics of situational motor tests in karate]. Unpublished thesis, University of Zagreb, Fakultet za fizičku kulturu.

Koropanovski, N., Dopsaj, M., \& Jovanović, S. (2008). Characteristics of Pointing Actions of Top Male Competitors in Karate at World and European level. Brazilian Journal of Biomotoric, 2(4), 241-251.

Костовски, Ж. (2004) Мерни карактеристики на моторните и спечифично моторичките тестови кај карате спортисти од различна хронолошка возрасm [Measuring features of motor and specific motor tests in karate athletes from different chronological age]. Unpoublished doctorial dissertation, University "Ss. Cyril and Methodius" of Skopje, Faculty of Physical Culture.

Костовски Ж. (2005) У тврдуванје на мерните карактеристики на одредени специфично моторни тестови за проценунување на специфична карате-координација, кај каратеспортистки пом^ади кадетки [Determining the measurement characteristics of certain specific motor tests for assessment of specific karate coordination in younger female karate athletes-cadets]. Физичка култура, 2, 115-118.

Kostovski, Ž., \& Georgiev, G. (2009a). Relijabilnost primenjenih testova za procenu specifične karate koordinacije kod vrhunskih karatista sa različite hronološke uzrasti, [Test reliability for assessment the appropriateness of specific coordination in elite karate athletes with different chron- ological ages]. In B. Mikić (Ed.), II Medunarodni simpozijum Sport $i$ zdravlje (pp. 127-130). Tuzla, BA: Fakultet za tjelesni odgoj i sport.

Kostovski, Ž., \& Georgiev, G. (2009b). Validnost testova za procenu specifične karate koordinacije kod 12 i 14 godišnjih karatista [Test validity tests for the assessment of specific coordination karate at 12 and 14 years old karate athletes]. In B. Mikić (Ed.), II Međunarodni simpozijum Sport $i$ zdravlje (pp. 120-126). Tuzla, BA: Fakultet za tjelesni odgoj i sport.

Kostovski, ̌̌., \& Georgiev, G. (2009c). Measure characteristics of motor tests for assessing rhythmic structure and explosive strength with karate athletes and non-athletes at the age of 12 . Sport scientific and practical aspect, 6(2), 37-42.

Kostovski, Ž, Mashik, Z, \& Gukanovik, N. (2011). Measuring performance of the strokes with leg (mavashi geri and ushiro geri) in karate sport. In. A. Biberović (Ed.), IV Međunarodni simpozijum Sport $i$ zdravlje (pp. 245-248). Tuzla, BA: Fakultet za tjelesni odgoj i sport..

Kuleš, B., \& Muratagić, Dž. (1993). Konstrukcija i validacija situacijsko-motoričkih testova za karatiste [Construction and validation of situational-motor tests for karate athletes]. Kineziologija, 25(1-2), 52-57.

Sertić, H., Vidranski, T., \& Segedi, I. (2010). Terenski testovi za procjenu specifičnih motoričkih sposobnosti karatista [Field tests for the assessment of specific motor skills karate athletes]. In I. Jukić, C. Gregov, S. Šalaj, L. Milanović, and T. Trost-Bobić (Eds.), VIII godišnja međunarodna konferencija Kondicijska priprema sportaša (pp. 223-226). Zagreb, HR: Kineziološki fakultet Sveučilišta u Zagre; Udruga kondicijskih trenera Hrvatske.

Received: October 13, 2012 Revision received: December 5, 2012 Accepted: December 30, 2012

Correspondence to: Žarko Kostovski, PhD Faculty of Physical Culture Đeleznička bb 1000 Skopje Macedonia

Phone: 0038970340797

Fax: 0038923119755

E-mail: zarkokostovski@hotmail.com 